\title{
Marek Kalinowski
}

Uniwersytet Mikołaja Kopernika, Torun

mkal@umk.pl; ORCID: 0000-0003-1106-4387

\section{Hans Nawiasky's views on tax law and tax-law relations}

\author{
http://dx.doi.org/10.12775/SIT.2018.006
}

\section{Introductory notes}

Hans Nawiasky is first of all known as a representative of the theory of state and law and constitutional law ${ }^{1}$. His works on the general theory of the state and law are still being published and

${ }^{1}$ Born in Graz in Austria in 1880, Hans Nawiasky was a professor whose scientific interests were very broad and included theory of law, constitutional law, administrative law, and financial law. He obtained a PhD in law in 1903 at the University of Vienna for the work titled Die Frauen im österreichischen Staatsdienst. After obtaining the degree of a habilitated doctor for the dissertation Deutsches und österreichisches Postrecht, in 1910 he began his work at the University of Vienna, where he dealt with the institutions of administrative law. In 1919 he was employed at the University of Munich as a professor of constitutional law which entailed the duty to conduct lectures on administrative and financial law. As a result he changed his scientific interests and began research on constitutional law and federalism. During this period, he published a work entitled Der Bundesstaat als Rechtsbegriff, which inaugurated his research aimed at the development of the theory of the state. At that time, his works devoted to tax law were also created. Moreover, Hans Nawiasky was active outside the University. In 1929 he became the head of the newly founded Instituts für Reichs- und Landesstaats- und Verwaltungsrecht. He was also one of the main advisors on constitutional matters of the government of Bavaria. In 1933 he became a victim of anti-Semitic speeches, as a result of which he emigrated to Switzerland, where he undertook research at the St. Gal- 
studied. His particularly appreciated views are concerned with the theory of the state which he perceived as a social fact and a legal phenomenon.

Nawiasky's works on tax law can be regarded as incidental if one is to judge them with regard to the entirety of his scholarly activity, which is relatively narrow in terms of quantity and volume. In fact his statements regarding tax law were to a certain extent incidental in character and were closely related to the Reichsabgabenordnung passed in 1919. They focused on the critical analysis of this act from the point of view of the theory of administrative law. Consequently, starting from 1921, five essays were published in 1921 and 1925, which in 1926 appeared in the collection entitled Steuerrechtliche Grundfragen ${ }^{2}$. In addition, he devoted to tax law several other articles ${ }^{3}$ and mentions in his works on the theory of law or constitutional law. In spite of the scarcity of these materials, his scholarly achievements can be considered significant. What is more, in the introduction to the Spanish edition of Steuerrechtliche Grundfragen 4 Klaus Vogel stated that "although it might seem that this book currently has only a historical value, it should be acknowledged that it has preserved its validity in relation to present times and as well as a provocative force that encourages scientific

len University. There he dealt with the general theory of law, deepening Hans Kelsen's pure theory of law. He also created his most popular works, including: Staatstypen der Gegenwart and Allgemeine Rechtslehre als System der rechtlichen Grundbegriffe. In 1947 once again he began to work at the University of Munich. He also took part in the works of Herrenchiemseer Konvents zu der Vorbereitung des Grundgesetzes, which prepared the first version of the Basic Law of the Federal Republic of Germany. In post-war period Hans Nawiasky published a 4-volume work entitled Allgemeine Staatslehre, a commentary to the Constitution of Bavaria as well as Die Grundgedanken des Grundgesetzes für die Bundesrepublik Deutschland. Systematische Darstellung und kritische Würdigung.

${ }^{2}$ H. Nawiasky, Steuerrechtliche Grundfragen, München 1926; Spanish edition: Cuestiones fundmentales de Derecho tributario, Madrid 1980.

${ }^{3}$ Einiges über steuerrechtliche Grundfragen, „Vierteljahresschrift für Steuer und Finanzrecht“ 1928, no. 2; Steuerrechtliche Grundbegriffe, „Sweizeriches Zentralblatt für Staats und Gemeindeverwaltung“ 1952, no. 23.

${ }^{4}$ H. Nawiasky, Cuestiones fundmentales de Derecho tributario, Madrid 1980. 
reflection. It certainly deserves to be read by every generation, as it is an important contribution of German jurisprudence to the financial and tax law"5.

The scientific achievements of $\mathrm{H}$. Nawiasky have also remained valid with regard to Polish tax law jurisprudence and should be carefully studied. Indeed, he disputed the regulation contained in art. 81 of Reichsabgabenordnung, pursuant to which a tax liability arises at the time of an occurrence of a taxable event, indicating that this is an inappropriate solution and one that disregards the achievements of administrative law jurisprudence. Meanwhile, the current regulation contained in art. $21 \mathrm{sec} .1$ points 1 and 2 of the Tax Code reflects precisely the theoretical concept defended by Nawiasky which was rejected in 1919 by the Reichsabgabenordnung. This in turn means that his concept may constitute a serious contribution to the theoretical analysis of the indicated provisions of the Polish law.

\section{The nature of the tax-law relationship in H. Nawiasky's concept}

The end of the nineteenth century marked the transition period between the idea of a police state and the rule of law. Hence, in a number of theoretical statements belonging to the first trend, one could find those saying that tax-law relations are relations of power and subordination. We may point out that such a position was taken by Otto Mayer, who acknowledged that in the said relationship the position of administration is superior to the taxpayer who is subordinate to it. Hence, according to him, tax-law relations arising between the public law association and taxpayers are not legal relations, but rather the relations of power and subordination ${ }^{6}$. Also, the successors and followers of O. Mayer assumed that the tax relationship is a pure relation of power, and not a legal relation-

\footnotetext{
${ }^{5} \mathrm{~K}$. Vogel, Introduccion a la edicion española (w:) H. Nawiasky, Cuestiones fundmentales de Derecho tributario, Madrid 1980, p. IX.

${ }^{6}$ O. Mayer, Le droit administratif allemand, v. 1, Paris 1903, p. 50 et seq.
} 
ship. Among them, attention should be paid to Franz Schneider, who in his work titled Das Abgabengewaltverhältnis. Grunzüge eines materiellen Teils ${ }^{7}$, undertakes to develop the general part of tax substantive law, as is indicated in the actual very title of his work. To him, the key to clarifying the concept of tax rests in the concept of the relationship of power (Abgabengewaltverhältnis), which is understood as a manifestation of sovereignty ${ }^{8}$.

As Schneider points out, the relationship of power and the obligation relationship constitute two types of legal relations. They occur in both administrative and in civil law ${ }^{9}$. He also notes that the difference between these relationships is very important. An obligation relationship is a bond in which one person is required to perform a specific service towards another person. In turn, what is referred to as the "relationship of power" expresses an abstract kind of authority through which one person may lead to the establishment of an obligation relationship ${ }^{10}$.

Taking this criterion into account, F. Schneider concludes that the tax relationship is precisely a relationship of power, as the will of the public body is imposed on the individual. However, he immediately makes the reservation that this last finding cannot be interpreted to mean that the will of the state is of an unlimited and absolute character. Like O. Mayer, he establishes that in line with the idea of the rule of law, the rule of law itself is subject to statutes. Without an express statutory provision, the state is not entitled to claim tax considerations from anyone. Nor is it permissible without a statutory basis to issue an administrative act, the content of which would impose an obligation to pay such considerations ${ }^{11}$. As Schneider argues, in the public-law sense, taxes are monetary considerations that must be paid to the state by virtue of a general rule in order to contribute to the public budget, in the

${ }^{7}$ F. Schneider, Das Abgabengewaltverhältnis. Grunzüge eines materiellen Teils, Tübingen 1918.

8 Ibidem, p. 7.

9 Ibidem, p. 4.

10 Ibidem, p. 6.

11 Ibidem, p. 9. 
fulfilment of the obligation arising when the condition laid down in the applicable legal order is met ${ }^{12}$.

Also in Italian tax law jurisprudence, the view was adopted that the tax relationship is a relationship of power. As an example, it can be pointed out that such a position was assumed by Vittorio Emanuele Orlando ${ }^{13}$.

The above theory of the tax-law relationship as the relation of power was questioned at the beginning of the $20^{\text {th }}$ century, as an inevitable consequence of the emergence of an idea of the state of law. As appears from previous considerations, the theory of a tax relation as a relation of power assumed that within its framework, tax authority is unlimited. Meanwhile, the idea of the state of law assumed that not only entities which are outside the state, but also the state itself and its organs are bound by the law they institute. It was difficult, therefore, to reconcile with it the views on the tax-law relationship understood as a relationship of power, within which the state stands beyond any control. Hence, as a counter-proposal to the indicated theory, which perceived the relationship between the state and private entities as vertical associations of power, at the beginning of the twentieth century the theory of a tax-law relationship understood as an obligation relationship appeared in the German doctrine of tax law. One of its representatives and fierce defenders was Hans Nawiasky ${ }^{14}$. This stance was a derivative of his scholarly approach manifesting itself in emphasising the strict legal connection of the state in order to achieve the greatest "balance of power" between the parties of the tax-law relationship when there is a dispute regarding the existence and amount of a tax liability ${ }^{15}$.

By typifying various possible situations in which the state and a passive tax entity may find each other, and which may arise in the context of indirect taxes, H. Nawiasky concluded that it is

12 Ibidem.

${ }^{13}$ On the of views of other representatives of Italian jurisprudence on the tax relationship as a relation of power, cf. e.g. E. Tosato, Sulla natura delle leggi tributarie, "Rivista di diritto finanziario e scienza delle finanze" 1939, no. 1, p. 309 et seq.

${ }^{14}$ K. Vogel, op.cit., p. XIV-XV.

${ }^{15}$ Ibidem, p. XIV. 
possible to distinguish two such substantive situations which are interrelated by an indirect or temporary situation of a procedural character. Therefore, the taxation process is divided into three consecutive phases. First, there is a "general tax liability" on the part of the passive entity, which Nawiasky called "the obligation to abolish tax by the tax administration" (Veranlangungspflicht) ${ }^{16}$. It arises when the passive entity in the tax-law relationship generates an event described in the tax norm. This is an obligation corresponding to the "tax claim" on the part of the state, i.e. the active entity in the legal relationship, that which Nawiasky referred to as "the right of tax assessment" (Veranlagungrecht). "The obligation for the taxpayer to accept the tax assessment performed by the tax administration", and the "right to tax assessment" attributable to the state, lead to the issuing by the body of an act of assessment that is of a constitutive nature. This very act (Gestaltungsakt) is in turn the source of a new legal situation. It establishes a "tax debt" (Steuerschuld) with regard to the entity remaining in a passive legal relationship, whilst the state, being an active entity of this relationship, becomes entitled to a "tax claim" (Steuerforderung). According to the terminology used by $\mathrm{H}$. Nawiasky, the latter situation of the passive entity is referred to as the "obligation to pay the tax amount" (Zahlungspflicht), whereas the situation of the active entity is referred to as "the right to claim tax payment" (Zahlungsforderung) ${ }^{17}$.

When evaluating the situation of a tax authority and a taxpayer remaining in a tax-law relationship, Nawiasky concluded that from a formal point of view, both entities are in the same situation as is the case when it comes to a private-legal obligation. Both entities, in relation to their rights and obligations, are equally bound by the provisions of the legal order. Therefore, since it is possible to speak of equality of private law entities, based on the same principle we must assume that such equality also exists with regard to tax liability ${ }^{18}$.

According to Nawiasky, the correctness of this observation cannot be influenced by the fact that in tax law the state is not only

\footnotetext{
${ }^{16}$ H. Nawiasky, Cuestiones fundamentales de derecho tributario, p. 21.

17 Ibidem.

${ }^{18}$ Ibidem, p. 53.
} 
a creditor, but also a legislator - an active actor in the legal order. The same situation also occurs when the state is a creditor in the civil law sphere, where equality between the state as a creditor and an individual as a debtor is recognised without any hesitation. In fact, equality or equalisation means being treated equally in the legal order ${ }^{19}$. Hence, it cannot be acknowledged that the state as an entity entitled to a tax liability is in a superior position as compared to the debtor. Its will towards the latter entity is not final, nor is it of an autonomous character. On the contrary, the state can only demand what the legal order has allocated to it ${ }^{20}$.

Next, Nawiasky notes that one cannot see the difference between tax and civil law relations in the fact that the implementation of tax liabilities has been handed over to the administration, so that the creditor's bodies decide about their own claims. Such a situation also occurs when the state acts as a civil creditor. Also in this case, the state authorities seek decisions regarding the civil rights of the state in judicial proceedings. In both cases it is the state that may exercise the right of enforcement.

According to Nawiasky, the phenomenon known as tax sovereignty does not refer to a tax liability, but solely to the tax act, just as state sovereignty, looked at from a general perspective, manifests itself solely in the legal order. Hence, it is completely wrong to characterise the tax liability as a relationship of power, while to a greater extent it constitutes an obligation relationship. Within its framework, an entity granted the rights resulting from the legal order does not have any sphere of action where it could arbitrarily raise claims against the liable entity, or where it could determine, by its own dominant will, what it is that the other entity must do or cease to do. It is the legal order itself that directly defines the claims of the authorised entity. In addition, the relationship of authority lies at the very core of the obligation relationship, namely the relationship of power between the state and the totality of entities that are subject to the legal order, i.e. the state governance as $\mathbf{s u c h}^{21}$.

\footnotetext{
19 Ibidem.

${ }^{20}$ Ibidem.

${ }^{21}$ Ibidem, pp. 53-54.
} 
The above perception of tax relations presented was also the reason why Hans Nawiasky became the first critic of art. 4 RAO where the principle of the economic interpretation of tax law was codified, and introduced into the act by Enno Becker remaining under the influence of the free law school. In his opinion this provision offered too much freedom when applying the tax $\operatorname{law}^{22}$.

\section{The structure of a tax-law relation}

The primary parties to tax-law relations are tax authorities and taxpayers. However, apart from them there may be other entities, such as payers or collectors of payments. The participants of such relations may also be third parties responsible for taxpayers' liabilities as well as the legal successors of taxpayers. Nevertheless, certain tax obligations may also be imposed on other persons, as for instance the obligation to provide information necessary to establish actual tax status. Some of these entities are bound by not one, but many legal obligations.

With such a state of affairs, the problem arises of whether, within the tax law, it is possible to distinguish multiple legal relationships structured around individual rights or obligations, or whether one should develop a legal relationship that would encompass all of these rights and obligations.

In the jurisprudence of civil law, it is generally accepted that in a situation where there are a number of related rights and obligations, as well as in a situation where there are more than two entities related via mutual rights and obligations, they should be perceived as a single complex legal relationship ${ }^{23}$. Indeed, such

22 Ibidem, pp. 19-20.

${ }^{23}$ S. Grzybowski, Stosunek cywilnoprawny [A Relation Under Civil Law] (in:) System prawa cywilnego. Część ogólna [The Civil Law System. General Part], v. I, ed. W. Czachórski, Ossolineum 1985, p. 182; ibidem, Wierzytelność i dług oraz uprawnienia i obowiazki [Liability and Debt as well as Rights and Obligations] (in:) System prawa cywilnego, Prawo zobowiązań - część ogólna [The Civil Law System. Obligations - General Part], v. III, p. 1, ed. Z. Radwański, Ossolineum 1985, pp. 44, 49-53; cf. P. Machnikowski, Struktura zobowiazania [The Struc- 
a presentation of complex legal relations makes it possible to reveal the close relationship that links the rights and obligations with respect to one legal institution, and to demonstrate the socioeconomic uniformity of a complex legal relationship ${ }^{24}$. Moreover, if within a complex legal relationship we were to distinguish simple legal relations relativised to particular rights and obligations, they could not become an object of a separate analysis detached from the analysis of the whole ${ }^{25}$.

In turn, in the theory of law, the concept of complex legal relations is at times directly negated ${ }^{26}$. In consequence, particular legal relationships that form a specific legal institution are to be treated as separate relations. Occasionally, in the theory of law the very idea of constructing complex legal relations is not negated; however, an indication is made that the concept of indivisibility of legal relations is ideological by nature. However, attention is drawn to the fact that in order to fully characterise such complex relationships, it is necessary to analyse particular simple component relations ${ }^{27}$.

Whereas in tax law it is possible to observe both these trends, part of the tax law jurisprudence used to and still does continue to represent the position indicating that tax-law relations should be depicted and analysed as simple relations. Nonetheless, there have been a number of representatives of the tax law doctrine who tried to construct models that would include all tax rights and obligations of tax law entities.

The representative of tax law jurisprudence who adopted the first of the two above-mentioned views was Hans Nawiasky. He concluded that when speaking about a tax liability, one first of all refers to the obligation to pay tax. It occupies the central place with

ture of an Obligation] (in:) System prawa prywatnego, Prawo zobowiązań - część ogólna [System of Private Law, Obligations - General Part], v. 5, ed. E. Łętowska, Warsaw 2013, p. 121.

${ }^{24}$ S. Grzybowski, Stosunek cywilnoprawny, p. 182.

25 Ibidem.

${ }^{26}$ K. Opałek, Prawo podmiotowe. Studium z teorii prawa [Rights in a Subjective Sense. A Study in the Theory of Law], Warsaw 1957, p. 421 et seq.

${ }^{27} \mathrm{Z}$. Ziembiński, Problemy podstawowe prawoznawstwa [Fundamental Problems of the Legal Sciences], Warsaw 1980, p. 363. 
all other liabilities revolving around it. The obligation to pay tax does not exhaust the tax relationship, as there is a whole range of legal relationships that spread around it, forming concentric circles and resulting in the capability to fulfil this first obligation ${ }^{28}$.

Among these other liabilities we may distinguish a group which is located on the periphery, and which allows the conducting of proceedings aimed at tax imposition ${ }^{29}$. He referred to such a group of liabilities as financial liabilities (Finanzpflichten), which at the same time constitute auxiliary liabilities (Hilfspflichten) ${ }^{30}$. They may be placed on the taxpayer, as well as on other persons without such a status. They may be imposed on these entities by tax laws, as well as by tax authorities under a financial order issued by them (Finanzbefeh $)^{31}$. All of these liabilities are classified as material liabilities ${ }^{32}$.

Despite the functional relationship between the obligation to pay and financial liabilities, the latter constitute a separate category of liabilities appearing in the tax law. They differ from the tax obligation by the fact that they do not consist in "giving" but "performing." Therefore, their aim is not to obtain cash inflows, as opposed to tax liabilities, whose purpose is precisely to obtain a given tax amount.

\section{The dispute regarding the formation of tax-law relations}

For a better understanding of F. Nawiasky's views on the formation of tax-law relations, they need to be embedded in the context of the current situation of tax law jurisprudence and its opinions about this issue.

${ }^{28}$ H. Nawiasky, Cuestiones fundamentales de Derecho tributario, p. 54.

${ }^{29}$ According to Nawiasky they include, for instance, the bookkeeping obligations, an obligation to provide information, submit a tax return, provide a balance sheet, etc. He also includes among them obligations resulting from liability; ibidem, p. 56-57.

${ }^{30}$ Ibidem, p. 55.

${ }^{31}$ Ibidem.

32 Ibidem, p. 57. 
The first ordered theoretical statements regarding the formation of tax-law relations began to appear in the literature at the end of the 19th century. Otto Mayer was the first to take a position on this matter. Owing to the principles governing the establishment and performance of a tax liability, he distinguished two types of taxes: fixed taxes and variable taxes. The characteristic feature of the former is that the tax act regulates all elements of their structure, including the tax rates ${ }^{33}$. In contrast, in variable taxes, tax laws regulate all elements of the tax structure, however the tax rates are determined parametrically by assigning a certain number to the subject of taxation. Therefore, the said act does not directly define the tax due, but indicates in what proportion the subject of taxation will be taxed once it is actually taxed.

A norm, which does not specify the tax rate, i.e. the amount of tax, O. Mayer considers incomplete and thus not having a direct legal effect. In order to make it function, it is necessary to fill this gap by determining the amount that will be required from the taxpayer. This task belongs to the tax administration.

Therefore, in the case of variable taxes ${ }^{34}$ it is necessary to determine the amount of tax due in each individual case and inform the taxpayer about it. From the point of view of the science of finance, this activity amounts to calculating the amount of tax. On the other hand, from a legal point of view, this is a sovereign act in which the amount of the debt is determined, and communicated though its service on the debtor ${ }^{35}$.

Such a sovereign act which assumes the form of a tax decision does not lead to the establishment of a tax-law relationship, and thus it is not a constitutive act ${ }^{36}$. The said relationship arises from the power of the law itself along with the occurrence of an event

${ }^{33}$ By a tax rate O. Mayer means a specific amount of tax that should be paid in connection with the occurrence of an event specified in the tax norm.

${ }^{34}$ According to O. Mayer this group of taxes includes direct taxes; O. Mayer, Le droit administratif allemand, v. 2, Paris 1904, p. 200 et seq.

35 Ibidem, p. 201.

${ }^{36}$ Mayer expressed an opinion that the act through which tax authorities ensure "proper application" of tax norms in individual cases is merely a simple "informational work"; ibidem, pp. 201 and 205. 
specified in the legal norm, i.e. once the conditions set out in the act are met ${ }^{37}$. However, without the issuance of a decision and communicating with a notification of the amount of tax due, there is no legal obligation to pay tax. Until the tax assessment decision is issued by the tax authority and delivered to the taxpayer, the taxpayer is not required to pay the tax. Moreover, the taxpayer himself cannot pay such tax ${ }^{38}$. It is only with an act of notification of the taxpayer of the amount of tax that makes it chargeable, and only from this moment can it be effectively paid. This act is also the basis for the initiation of enforcement proceedings against the taxpayer.

A similar perception of this problem was presented by F. Myrbach-Rheinfeld. He concluded that from the legal point of view, taxes are cash benefits to public law entities that impose tax laws in the situations specified therein, without the need for any other legal title that would give rise to a financial liability ${ }^{39}$. Next, he proposed a distinction between the "tax obligation" (Abgabenpflicht), which constitutes an obligation to pay (Abgabenverbindlichkeit) and the "tax debt" (Abgabenschuld) as well as the "right to taxation" (Anspruch auf die Abgabe) and the "tax liability" (Abgabenforderung). Hence, on the one hand he distinguished the passive and active aspect of taxation, whilst on the other - its passive and specific sphere $^{40}$.

The obligation to pay tax and the complementary right to taxation do not arise simply as a result of the establishment of a relevant legal provision, as the provision itself only creates the title from which they will result. On the other hand, the tax liability and the right to tax arise when factual circumstances regulated in the tax law rule occur. However, even at this point, the state cannot demand that a particular entity pays the defined amount of a tax consideration $^{41}$. Thus, F. Myrbach-Rheinfeld does not link an oc-

\footnotetext{
37 Ibidem, p. 205.

${ }^{38}$ Ibidem, p. 206.

${ }^{39}$ F. Myrbach-Rheinfeld, Précis de droit financier, Paris 1910, p. 115.

40 Ibidem, p. 117.

${ }^{41}$ Ibidem, p. 116.
} 
currence of any factual circumstances regulated in the tax law to the emergence of a tax debt and the corresponding tax liability, but merely to the arising of a "tax liability" and the corresponding "right to taxation". At this point, the administrative authority only obtains the right to determine the person on whom the obligation rests along with the amount of the consideration. According to F. Myrbach-Rheinfeld, also the mere issuance of a payment order by the tax authority does not entail the emergence of a tax debt. This is the result of its service on the obligated person. It is only at this moment that a tax debt arises and the taxpayer becomes a debtor ${ }^{42}$. From that moment, until the payment deadline, he is obliged to fulfil the duty of payment of the specified tax consideration. After this date, the tax may be compulsorily enforced from the debtor as an outstanding tax liability ${ }^{43}$.

To F. Myrbach-Rheinfeld, it is the tax debt (Abgabenschuld) that forms a legal relationship under which a particular person is required to pay a consideration that is a strictly defined as to its substance and scope, within a strictly defined period. When the date of chargeability of tax arrives, the tax may be compulsorily levied as an outstanding tax liability (Rückstand $)^{44}$.

Similarly to O. Mayer, F. Myrbach-Rheinfeld determined that a sovereign administrative act which gives rise to a tax debt, and thus forms a tax-law relationship, is a declarative act, as the conditions of an occurrence of the obligation to pay the consideration as well as its scope must be specified by the act, whereas the administrative body itself only determines whether in a particular case such conditions were met by an individually specified person and it is required to draw appropriate legal consequences ${ }^{45}$.

These doctrinal proposals led to the adoption by jurisprudence of the distinction between a tax liability and a tax debt, and, on the part of an active entity their correlates: a tax claim and a tax liability. Consequently, it was decided that the "tax obligation"

\footnotetext{
${ }^{42}$ Ibidem, p. 204.

43 Ibidem, p. 118.

${ }^{44}$ Ibidem.

${ }^{45}$ Ibidem, p. 137.
} 
arises as a result of an occurrence of a taxable event specified in tax norm hypothesis, whereas the "tax debt" arises only as a result of an issuance of a sovereign administrative act. Once the tax authority delivers to the taxpayer the administrative act imposing the obligation to pay the consideration, the latter becomes obliged to pay the tax debt. Upon the service of the said act, the taxpayer becomes a "debtor" (Schuldner), whereas on the part of the state a claim arises (Forderung) ${ }^{46}$.

The Reichsabgabenordnung passed on December 13, 1919 departed from this theoretical concept. Sec. 81 para. 1 of this act stipulates that the tax debt arises when factual circumstances occur. Thus, the resulting structure of a legal relation of tax obligation assumed that the administrative decision regarding the assessment of direct taxes ceased to be an "order of a constitutive nature" (Befehle mit konstitutivem Charakter). As was concluded by Nawiasky, it lost the character of a "constitutive act" (Gestaltungsakt) that established rights and obligations and became a simple "declarative act" (Festellungsakt) ${ }^{47}$. According to him, this undermined one of the most important tax distinctions in the tax literature, which accounts for direct taxes, i.e. such as those which should become the subject of a tax assessment (veranlagten Abgaben) and indirect taxes which are not defined based on an assessment (Nicht veranlagten Abgaben). As pointed out by Nawiasky with regard to taxes "subject to an assessment", traditionally it was assumed that the constitutive decision of the tax authorities issued after an occurrence of a taxable event as stipulated by the act resulted in the obligation to pay a defined tax amount; whilst with regard to the latter, the obligation to pay resulted directly from the act, without the need to take action by the administration" 48 .

46 This provision was concerned only with direct taxes, and therefore was such that an assessment was made by way of an administrative act. On the other hand, it did not concern indirect taxes which were not subject to assessment, and in relation to which the tax debt arose at the time of an occurrence of a taxable event.

${ }^{47}$ H. Nawiasky, Cuestiones fundmentales de Derecho tributario, p. 86.

${ }^{48}$ Ibidem, p. 21. 
Nawiasky did not agree with the consequences of the regulation contained in $\S 81$ para. 1 of Reichsabgabenordnung, which in his opinion, on the one hand, led to the confusion of direct and indirect taxes, whilst on the other hand, to the confusion of the concept of a tax obligation and tax debt. He maintained that owing to the occurrence of a taxable event regulated by the Act, a legal situation arises, in which the passive entity generates a general "tax obligation" (Steuerplicht) ${ }^{49}$, which Nawiasky chose to refer to as an "obligation to accept the administrative assessment"

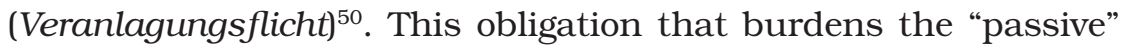
side of the tax relation, corresponds on the side of the state, i.e. the active entity, to the "tax claim" (Steueranspruch), which in turn Nawiasky calls the "right to a tax assessment" (Veranlagungrecht).

The facts of the arising of the taxpayer's "obligation to accept administrative tax assessment" and the authority's "right to a tax assessment", which were referred to by other representatives of tax law jurisprudence as a "tax obligation" and "tax claim" respectively, lead to the tax assessment act. This "constitutive act" of tax assessment (Gestaltungsakt) is in turn the source of a new legal situation. It leads to the occurrence of a "tax debt" (Steuerschuld) and a "tax liability" (Steuerforderung), which is called by Nawiasky the "obligation to pay a tax amount" (Zahlungsplicht) and the "right to demand payment of a tax amount of tax" (Zahlungsforderung) respectively.

Despite some differences in the terminology that exist between German tax law and H. Nawiasky's texts ${ }^{51}$, one can say that his

49 The term Steuerpflicht is used to describe an obligation of a general nature, a subordination understood as the possibility of being taxed, or rather as a potential possibility of becoming subject to taxation.

${ }^{50}$ Ibidem, p. 21.

${ }^{51}$ It is worth noting, however, that $\mathrm{H}$. Nawiasky did not always consistently use the terms "obligation to accept tax assessment" and "the right to tax assessment" as well as "the obligation to pay the tax amount" and "the right to demand payment of the tax amount". He frequently used the same terms as the entire tax law jurisprudence, i.e. "tax obligation" (Steuerpflicht) and "tax claim". (Steueranspruch) and "tax debt" (Steuerschuld) or "tax liability" (Steuerforderung); cf. ibidem. 
views are fully consistent with the views of his predecessors. In particular, he accepted the view of Myrbach-Rheinfeld, who used the differentiation between the "tax obligation" (Abgabenverbindlichkeit) and "tax debt" (Abgabenschuld), and in consequence he held that due to the occurrence of a taxable event, a tax relationship of a general nature is established, whereas the actual tax obligation, i.e. the obligation to "deliver" arises only when the taxpayer and the tax amount were determined by way of an administrative act ${ }^{52}$.

Nawiasky found that the distinction in the process of taxation of two separate legal situations interspaced by the tax assessment act (Steuerveranlagung) is not characteristic of the tax law alone. As an example, he recalled military law and the theoretical findings of Paul Laband ${ }^{53}$. He pointed out that also in this case one can observe an "obligation to perform military service" and separate "obligations to appear in the ranks". The first one arises as soon as the legally binding age for military service is reached and is connected with the obligation to undergo recruitment, i.e. to be enrolled in the list kept by the army. On the other hand, the latter obligation, since it does not arise directly as a result of a general obligation to perform military service, must be notified to the person concerned by means of a sovereign act.

When analysing the aforementioned dogmatic structure revealed in another branch of public law, Nawiasky arrived at the conclusion that it should also be adopted in the tax law, as in his opinion it fully explains the normative construction of this branch of law. Hence his criticism of the regulation contained in Sec. 81 Para. 1 of Reichsabgabenordnung.

When assessing Nawiasky's views on the formation of the basic tax-law relationship, Klaus Vogel said that they were futile ${ }^{54}$ since despite their solidity they could not change the law. From a historical perspective, such an assessment is not fully justified. The doctrinal proposals put forward by him were taken into account in part in the Abgabenordnung of 1977. The new German tax ordinance

\footnotetext{
52 F. Myrbach-Rheinfeld, op.cit., pp. 116-117.

${ }^{53}$ P. Laband, Le droit public de l'Empire allemand, t. V, Paris 1903, pp. 223.

${ }^{54}$ K. Vogel, op.cit., p. XIV.
} 
states in Sec. 38 that "claims related to the tax debt relationship arise when a fact occurs to which the act links the obligation to fulfil the tax obligation". And so, the concept of a tax claim was reintroduced to German tax law, a concept whose omission in Sec. 81 Para. 1 of Reichsabgabenordnung was criticised by Nawiasky.

\section{Conclusions}

Hans Nawiasky undoubtedly did not belong among the representatives of tax law jurisprudence who were the first to become involved in the development of the institution of the tax law. Nor did he not belong among those who devoted themselves entirely to the science of tax law, as he had a greater share in the attainment of the theory of state and constitutional law. Nevertheless, his contribution to the science of tax law is significant. This is evidenced by the fact that his Steuerrechtliche Grundfragen are still being studied today. His reflections on the internal structure of the tax-law relationship and its establishment are particularly interesting and inspiring. The latter not only influenced the content of the Abgabenordnung of 1977, but may be an inspiration for modern tax law. His considerations regarding the nature of the tax relationship as an obligation relation are equally important. Not only did they inspire representatives of tax law jurisprudence throughout the 20th century, they can and should form the basis for reflection for the modern tax legislator in many countries to whom the idea of equality between the state and tax authorities representing it on the one hand and the taxpayer on the other still seems to be a far-reaching postulate, although it might seem that the rule of law has taken root in modern jurisprudence for good.

Therefore, we may repeat after Kalus Vogel that "although it might seem that Nawiasky's works currently represent only a historical value, it should be acknowledged that they have preserved their validity in relation to present times and as well as provocative force that encourages scientific reflection". 


\title{
STRESZCZENIE
}

\author{
Poglądy Hansa Nawiasky'ego na prawo \\ i stosunki podatkowoprawne
}

W artykule przedstawiono poglądy Hansa Nawiasky'ego dotyczące podstawowych zagadnień prawa podatkowego. W pierwszej kolejności zaprezentowano jego stanowisko dotyczące charakteru stosunku podatkowoprawnego. Według niego stosunek ten należy postrzegać jako stosunek zobowiązaniowy, nie zaś jako stosunek władztwa. Następnie zaprezentowano jego poglądy na strukturę stosunków podatkowoprawnych. Przedstawiono także spór o powstawanie stosunków podatkowoprawnych, w którym H. Nawiasky zajął stanowisko, iż stosunek prawny zobowiązania podatkowego powstaje wskutek wydania i doręczenia podatnikowi aktu administracyjnego, nie zaś wskutek zajścia zdarzenia unormowanego w hipotezie normy podatkowej.

Słowa kluczowe: Hans Nawiasky; prawo podatkowe; stosunki podatkowoprawne; charakter stosunków podatkowoprawnych; struktura stosunków podatkowoprawnych; powstawanie stosunków podatkowoprawnych

\section{SUMMARY}

Hans Nawiasky's views on tax law and tax-law relations

The article presents Hans Nawiasky's views on the basic issues of the tax law. First, Nawiasky's position regarding the nature of the tax-law relationship is presented, according to which the tax relationship should be seen as an obligation relationship and not as a relationship of power. Next, the article presents his views on the structure of a tax relationship and, finally, the author describes H. Nawiasky's point of view on the formation of a tax law relationship, in which $\mathrm{H}$. Naviasky takes the stance that the legal relationship of tax liability arises as a result of an issuance and service to the taxpayer of an administrative act, and not as a result of an occurrence of a tax event regulated in the tax law.

Keywords: Hans Nawiasky; tax law; tax-law relationship; nature of the tax-law relationship; structure of a tax-law relation; formation of tax-law relations 


\section{BIBLIOGRAPHY}

Grzybowski S., Stosunek cywilnoprawny (in:) System prawa cywilnego. Część ogólna, v. I, ed. W. Czachórski, Ossolineum 1985.

Grzybowski S., Wierzytelność i dług oraz uprawnienia i obowiazki (in:) System prawa cywilnego. Prawo zobowiazań - część ogólna, v. III, p. 1, ed. Z. Radwański, Ossolineum 1981.

Laband P., Le droit public de l'Empire allemand, t. V, Paris 1903.

Machnikowski P., Struktura zobowiazania [The Structure of an Obligation] (in:) System prawa prywatnego, Prawo zobowiązan - część ogólna, v. 5, ed. E. Łętowska, Warsaw 2013.

Mayer O., Le droit administratif allemand, v. 1-2, Paris 1903-1904.

Myrbach-Rheinfeld F., Précis de droit financier, Paris 1910.

Nawiasky H., Einiges über steuerrechtliche Grundfragen, „Vierteljahresschrift für Steuer und Finanzrecht" 1928, no. 2.

Nawiasky H., Steuerrechtliche Grundbegriffe, „Sweizeriches Zentralblatt für Staats und Gemeindeverwaltung“ 1952, no. 23.

Nawiasky H., Steuerrechtliche Grundfragen, München 1926; Spanish edition: Cuestiones fundmentales de Derecho tributario, Madrid 1980.

Opałek K., Prawo podmiotowe. Studium z teorii prawa [Rights in a Subjective Sense. A Study in the Theory of Law], Warsaw 1957.

Schneider F., Das Abgabengewaltverhältnis. Grunzüge eines materiellen Teils, Tübingen 1918.

Tosato E., Sulla natura delle leggi tributarie, "Rivista di diritto finanziario e scienza delle finanze" 1939 , no. 1 .

Vogel K., Introduccion a la edicion española (in:) H. Nawiasky, Cuestiones fundmentales de Derecho tributario, Madrid 1980.

Ziembiński Z., Problemy podstawowe prawoznawstwa [Fundamental Problems of the Legal Sciences], Warsaw 1980. 
